Correspondence

Derek R. Lovley

dlovley@microbio.umass.edu

\section{Rhodoferax ferrireducens sp. nov., a psychrotolerant, facultatively anaerobic bacterium that oxidizes acetate with the reduction of $\mathrm{Fe}(\mathrm{III})$}

\author{
Kevin T. Finneran,† Claudia V. Johnsen and Derek R. Lovley \\ Department of Microbiology, University of Massachusetts, Amherst, MA 01003, USA
}

\begin{abstract}
To further investigate the diversity of micro-organisms capable of conserving energy to support growth from dissimilatory $\mathrm{Fe}$ (III) reduction, $\mathrm{Fe}$ (III)-reducing micro-organisms were enriched and isolated from subsurface sediments collected in Oyster Bay, VA, USA. A novel isolate, designated $\mathrm{T}_{118}{ }^{\mathrm{T}}$, was recovered in a medium with lactate as the sole electron donor and $\mathrm{Fe}(\mathrm{III})$ as the sole electron acceptor. Cells of $\mathrm{T}_{118^{\top}}$ were Gram-negative, motile, short rods with a single polar flagellum. Strain $\mathrm{T}_{11} 8^{\mathrm{T}}$ grew between $\mathrm{pH} 6 \cdot 7$ and $7 \cdot 1$, with a temperature range of $4-30^{\circ} \mathrm{C}$. The optimal growth temperature was $25^{\circ} \mathrm{C}$. Electron donors utilized by strain $\mathrm{T} 118^{\top}$ with $\mathrm{Fe}(\mathrm{III})$ as the sole electron acceptor included acetate, lactate, malate, propionate, pyruvate, succinate and benzoate. None of the compounds tested was fermented. Electron acceptors utilized with either acetate or lactate as the electron donor included Fe(III)-NTA (nitrilotriacetic acid), Mn(IV) oxide, nitrate, fumarate and oxygen. Phylogenetic analysis demonstrated that strain $\mathrm{T}^{118^{\top}}$ is most closely related to the genus Rhodoferax. Unlike other species in this genus, strain $\mathrm{T}_{118^{\top}}$ is not a phototroph and does not ferment fructose. However, phototrophic genes may be present but not expressed under the experimental conditions tested. No Rhodoferax species have been reported to grow via dissimilatory $\mathrm{Fe}(\mathrm{III})$ reduction. Based on these physiological and phylogenetic differences, strain $\mathrm{T}_{118^{\top}}$ (=ATCC BAA-621 ${ }^{\top}=$ DSM $15236^{\top}$ ) is proposed as a novel species, Rhodoferax ferrireducens sp. nov.
\end{abstract}

\section{INTRODUCTION}

$\mathrm{Fe}(\mathrm{III})$ is often an abundant electron acceptor for microbial respiration in subsurface environments and aquatic sediments (Lovley, 2000a). Until recently, there has been much less investigation into the diversity of $\mathrm{Fe}(\mathrm{III})$-reducing micro-organisms than that of micro-organisms carrying out other forms of respiration. However, it is becoming increasingly apparent that there is a wide phylogenetic diversity of Bacteria and Archaea capable of conserving energy to support growth from electron transport to $\mathrm{Fe}$ (III) (Lovley, 2000a).

$\mathrm{Fe}(\mathrm{III})$-reducing micro-organisms that can use acetate as an electron donor are of interest because acetate is an

Published online ahead of print on 4 October 2002 as DOI 10.1099/ ijs.0.02298-0.

tPresent address: GeoSyntec Inc., 629 Massachusetts Avenue, Boxborough, MA 01719, USA.

Abbreviations: AQDS, anthraquinone-2,6-disulfonate; NTA, nitrilotriacetic acid; PHA, poly-hydroxyalkanoate; RDP, Ribosomal Database Project.

The GenBank/EMBL/DDBJ accession number for the 16S rDNA sequence of strain $\mathrm{T}^{118^{\top}}$ is $\mathrm{AF} 435948$. important intermediate in the anaerobic degradation of organic matter in sedimentary environments (Lovley \& Chapelle, 1995). Micro-organisms capable of oxidizing acetate with the reduction of $\mathrm{Fe}$ (III) include Geobacter and Desulfuromonas species within the family Geobacteraceae in the $\delta$-Proteobacteria (Lovley, 2000a), as well as Geothrix fermentans (Coates et al., 1999) and Geovibrio ferrireducens (Caccavo et al., 1996). The Fe(III)-reducing hyperthermophilic Archaea species Geoglobus ahangari (Kashefi et al., 2001) and Ferroglobus placidus (Tor et al., 2001) are also capable of acetate oxidation. These organisms are all strict anaerobes. However, a facultatively anaerobic $\gamma$-Proteobacterium capable of acetate oxidation, Pantoea agglomerans SP1, was recently described (Francis et al., 2000).

Most previously studied $\mathrm{Fe}(\mathrm{III})$-reducing micro-organisms have an optimal growth temperature of $20-30{ }^{\circ} \mathrm{C}$, but thermophilic and hyperthermophilic Fe(III)-reducing microorganisms have also been described (Greene et al., 1997; Kashefi \& Lovley, 2000; Lovley, 2000b; Tor et al., 2001; Vargas et al., 1998). There is less information on Fe(III)reducing micro-organisms growing at lower temperatures, but several psychrophilic enrichment cultures were 
recently reported to reduce $\mathrm{Fe}$ (III) at temperatures as low as $0{ }^{\circ} \mathrm{C}$ (Zhang et al., 1999). However, pure cultures of psychrotolerant, $\mathrm{Fe}(\mathrm{III})$-reducing micro-organisms have not previously been reported.

As part of a study to characterize the diversity of metalreducing micro-organisms in subsurface environments, aquifer material from a Department of Energy subsurface study site in Oyster Bay, VA, USA, was used as an inoculum for the enrichment and isolation of Fe(III)-reducing microorganisms. Several isolates were obtained from various enrichments. Here we report on one such isolate, which is a novel facultatively anaerobic, acetate-oxidizing, $\mathrm{Fe}$ (III)reducing micro-organism capable of growing at temperatures as low as $4{ }^{\circ} \mathrm{C}$. It is most closely related to micro-organisms in the genus Rhodoferax, but unlike Rhodoferax species, it did not grow as a photosynthetic micro-organism under the experimental conditions provided.

\section{METHODS}

Origin of enrichment cultures and isolate. Sediment from a variety of locations and depths at a site in Oyster Bay, VA, was collected as part of an ongoing collaboration to characterize metalreducing micro-organisms at Department of Energy facilities. Sediment was sealed in anaerobic canisters for transport, and enrichments were begun upon its arrival in the laboratory. The sediment that served as an inoculum for this culture was designated site T1, depth 18 feet $(5 \cdot 5 \mathrm{~m})$. Hence the first strain isolated from this sediment was designated $\mathrm{T} 118^{\mathrm{T}}$.

Media and growth conditions. Techniques for strict anaerobic culture were used throughout. The enrichment medium was a defined freshwater medium (Lovley et al., 1993) that contained $10 \mathrm{mM}$ lactate as the electron donor and $100 \mathrm{mmol} \mathrm{l}^{-1}$ poorly crystalline $\mathrm{Fe}$ (III) oxide as the sole electron acceptor. The medium $(10 \mathrm{ml})$ was dispensed in anaerobic pressure tubes and bubbled with $\mathrm{N}_{2} / \mathrm{CO}_{2}(80: 20, \mathrm{v} / \mathrm{v})$ to remove dissolved oxygen. The final $\mathrm{pH}$ was approximately $6 \cdot 7$. The enrichment culture was initiated with a $1 \mathrm{~g}$ sediment inoculum. The cultures were incubated at $20^{\circ} \mathrm{C}$ in the dark. Positive $\mathrm{Fe}(\mathrm{III})$-reducing enrichments were transferred $(10 \%$ inoculum) at least five times.

To obtain pure-culture isolates, the enrichment was streaked on a similar medium solidified with purified agar (1.5\%) in wide-mouthed glass tubes (Bellco Glass) which were then sealed with a butyl stopper. The slant medium differed in that $\mathrm{Fe}$ (III) chelated with nitrilotriacetic acid (NTA) was used in lieu of poorly crystalline Fe(III) oxide. Distinct colonies were picked and restreaked at least three times on solid agar slants, before being suspended in liquid media. Tests for phototrophic growth utilized two different types of medium. The first was a standard phototrophic growth medium adapted from Brock et al. (1994). The second was adapted from the original characterization of the genus Rhodoferax (Hiraishi et al., 1991). Electron donors utilized to test for phototrophic growth included fructose, acetate, hydrogen and succinate.

Characterization of anaerobic growth and electron donor and acceptor utilization. Cells were incubated at 4 or $25^{\circ} \mathrm{C}$ for all growth and donor/acceptor utilization experiments. Cells were enumerated with epifluorescent microscopy (Hobbie et al., 1977). Acetate was quantified by using HPLC. Electron donor utilization was evaluated with $10 \mathrm{mM} \mathrm{Fe}(\mathrm{III})-\mathrm{NTA}$ as the sole terminal electron acceptor. Lactate and acetate were tested separately as electron donors for studies on the range of electron acceptors reduced. Fe(II) was assayed with ferrozine as described previously (Lovley \& Phillips, 1987). Reduction of all other electron acceptors was determined visually by observing precipitation, colour change or turbidity.

Identification of poly-hydroxyalkanoate (PHA) inclusions. PHA inclusion bodies were identified by staining with Nile blue A, as described by Rees et al. (1992).

165 rDNA and phylogenetic analysis. Cells grown on lactate and $\mathrm{Fe}(\mathrm{III})-\mathrm{NTA}$ were collected by centrifugation, and genomic DNA was extracted using the GNOME DNA Isolation Kit (Bio 101). Almost the entire $16 \mathrm{~S}$ rDNA of strain $\mathrm{T} 118^{\mathrm{T}}$ was amplified using primers 8 Forward (5'-AGAGTTTGATCCTGGCTCAG-3') (Eden et al., 1991) and 1492 Reverse (5'-GGTTACCTTGTTACGACTT-3'). PCR amplification mixtures (total $100 \mu \mathrm{l}$ ) contained $10 \mu \mathrm{l} 10 \times$ buffer, $8 \mu \mathrm{ldNTPs}(200 \mu \mathrm{m}), 2 \mu \mathrm{l}$ BSA $\left(400 \mathrm{ng}^{-1}\right), 5 \mu \mathrm{l}$ DMSO, $3 \mu \mathrm{l}$ primer, $0.5 \mu \mathrm{l}$ genomic DNA template and $2.5 \mathrm{U}$ AmpliTaq (PerkinElmer Cetus). Amplification was performed in a PTC-200 Peltier Thermal Cycler (MJ Research) with an initial denaturation step at $96^{\circ} \mathrm{C}$ for $2 \mathrm{~min}$, followed by 20 cycles of $95^{\circ} \mathrm{C}$ for $30 \mathrm{~s}$, $50{ }^{\circ} \mathrm{C}$ for $30 \mathrm{~s}$ and $72{ }^{\circ} \mathrm{C}$ for $45 \mathrm{~s}$, concluded by a final extension at $72{ }^{\circ} \mathrm{C}$ for $10 \mathrm{~min}$. PCR amplification products were prepared for sequencing using a QIAquick PCR Purification kit (Qiagen). DNA sequencing was performed by the Orono DNA Sequencing Facility at the University of Maine. Complete bidirectional sequences were obtained from the PCR amplification product.

The sequences were compared to the GenBank and Ribosomal Database Project (RDP) databases using the BLAST (National Center for Biotechnology Information) and SIMILARITY_RANK (RDP) algorithms. The secondary structure was verified manually. The sequences were aligned with related $16 \mathrm{~S}$ rDNA sequences from GenBank and the RDP using the Wisconsin Package version 10 sequence editor (Genetics Computer Group). Phylogenetic trees were inferred using the distance, maximum-likelihood and parsimony tools of PAUP ${ }^{*}$ (Swofford, 1998).

\section{RESULTS AND DISCUSSION}

\section{Enrichment and isolation}

Sediments from the Oyster Bay site were inoculated into anaerobic medium that contained lactate as the electron donor and poorly crystalline $\mathrm{Fe}(\mathrm{III})$ oxide as the potential electron acceptor. A positive enrichment, designated $\mathrm{T} 118^{\mathrm{T}}$, reduced the $\mathrm{Fe}(\mathrm{III})$ oxide; this was visually apparent by the colour change from reddish-brown to black and the formation of $\mathrm{Fe}(\mathrm{II})$, as determined by the ferrozine assay. This enrichment culture was transferred five consecutive times with continued $\mathrm{Fe}$ (III) reduction. An aliquot of the enrichment culture was then streaked onto the solidified medium in which $\mathrm{Fe}(\mathrm{III})$ was provided as $\mathrm{Fe}(\mathrm{III})-\mathrm{NTA}$. Only one type of colony grew on these slants; the colonies were glossy white, smooth, round and convex. A single colony was resuspended in liquid medium with lactate as the electron donor and $\mathrm{Fe}(\mathrm{III})-\mathrm{NTA}$ as the electron acceptor. This culture continued to reduce $\mathrm{Fe}$ (III)-NTA in consecutive transfers.

Cells that grew in this medium were short, straight, motile rods, approximately $3-5 \mu \mathrm{m}$ long and $1 \mu \mathrm{m}$ wide (Fig. 1 ). All cells had a single, polar flagellum (Fig. 1). Cells stained Gram-negative during all growth phases, and did not form visible spores under any of the growth conditions tested. 


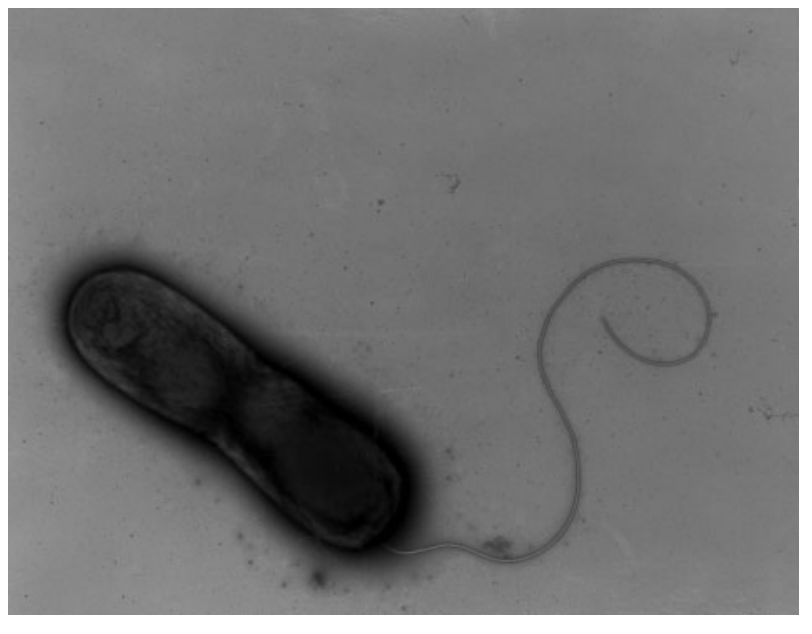

Fig. 1. Negatively stained electron micrograph of strain $T 118^{\top}$ showing the rod shape and the single polar flagellum.

However, cells in carbon-rich medium did produce inclusion bodies that were apparent under phase-contrast and electron microscopy. These inclusions were later identified as PHA by staining with Nile blue A and imaging with UV light, as described by Rees et al. (1992).

\section{Electron donors and acceptors utilized}

Strain $\mathrm{T} 118^{\mathrm{T}}$ also grew with acetate as the electron donor (Fig. 2). Fe(III)-NTA reduction was accompanied by an increase in cell number and a loss of acetate (Fig. 2). The stoichiometry of acetate consumption and $\mathrm{Fe}$ (III) reduction

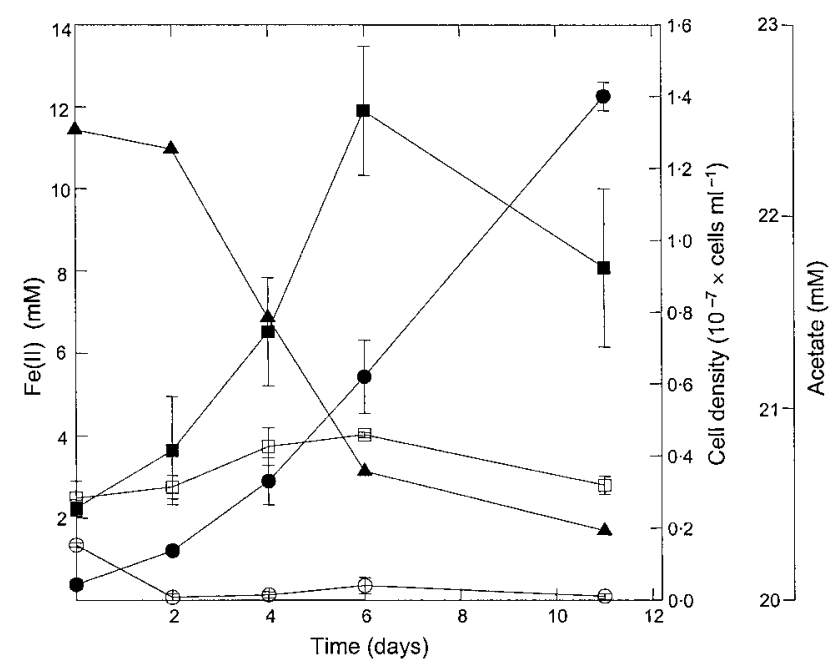

Fig. 2. Increase in cell number, production of Fe(II) and acetate consumption in cultures of $\mathrm{T}_{118^{\top}}$ at $25^{\circ} \mathrm{C}$. $\bullet, \mathrm{Fe}(\mathrm{II})$ with acetate; $\bigcirc, \mathrm{Fe}(\mathrm{II})$ without acetate; $\mathbf{\square}$, cell density with acetate; $\square$, cell density without acetate; $\boldsymbol{\Delta}$, acetate. Results are the means of triplicate analyses. Error bars represent one standard deviation. was consistent with the metabolism of acetate according to the reaction:

$$
\mathrm{CH}_{3} \mathrm{COO}^{-}+2 \mathrm{H}_{2} \mathrm{O}+8 \mathrm{Fe}(\mathrm{III}) \rightarrow 2 \mathrm{CO}_{2}+7 \mathrm{H}^{+}+8 \mathrm{Fe}(\mathrm{II})
$$

The electron donors utilized in media with $20 \mathrm{mM} \mathrm{Fe}(\mathrm{III})-$ NTA serving as the sole electron acceptor included acetate, lactate, propionate, pyruvate and malate (all $20 \mathrm{mM}$ ), succinate $(10 \mathrm{mM})$ and benzoate $(1 \mathrm{mM})$. Under the same conditions, the following compounds were not utilized: formate, butyrate, ethanol, methanol or glycerol (all $20 \mathrm{mM}$ ), caproate, isobutyrate, valerate, butanol or propanol (all $10 \mathrm{mM})$, or hydrogen $(160 \mathrm{kPa})$. Yeast extract $(0 \cdot 1 \%)$ did not support growth. Strain $\mathrm{T} 118^{\mathrm{T}}$ did not grow by converting $\mathrm{H}_{2}$ and $\mathrm{CO}_{2}$ to acetate and it did not grow phototrophically in either of the phototroph media that were tested. Strain $\mathrm{T} 118^{\mathrm{T}}$ did not ferment any of the compounds tested.

The electron acceptors utilized in media with $20 \mathrm{mM}$ lactate serving as the electron donor included Fe(III)-NTA and $\mathrm{Mn}$ (IV) oxide (both $10 \mathrm{mM}$ ), fumarate and nitrate (both $20 \mathrm{mM}$ ) and atmospheric oxygen. The following electron acceptors were not utilized: poorly crystalline Fe(III) oxide $(100 \mathrm{mM}), \mathrm{Fe}(\mathrm{III})$ citrate $(50 \mathrm{mM})$, anthraquinone-2, 6-disulfonate (AQDS) or chromium(VI) (both $5 \mathrm{mM}$ ), cobalt-EDTA $(0 \cdot 05 \mathrm{mM})$, uranium(VI) $(2 \cdot 5 \mathrm{mM})$, elemental sulfur $\left(1 \mathrm{~g} \mathrm{l}^{-1}\right)$, nitrite, selenate or selenite (all $\left.10 \mathrm{mM}\right)$, or sulfate, sulfite or thiosulfate (all $20 \mathrm{mM}$ ). A similar pattern was observed with acetate as the electron donor, with the exception that nitrate did not serve as an electron acceptor for growth on acetate.

$\mathrm{T} 118^{\mathrm{T}}$ is only the second facultatively anaerobic microorganism known to oxidize acetate with the reduction of $\mathrm{Fe}$ (III), the first being 'Shewanella saccharophilia' strain GC29 (Coates et al., 1998). It is the first facultatively anaerobic organism found to use benzoate as an electron donor for $\mathrm{Fe}$ (III) reduction. Strain $\mathrm{T} 118^{\mathrm{T}}$ is unusual amongst $\mathrm{Fe}(\mathrm{III})$ reducing micro-organisms in its inability to reduce AQDS, as most $\mathrm{Fe}$ (III)-reducing micro-organisms, including hyperthermophilic Archaea species, can use this electron acceptor (Lovley, 2000a; Lovley et al., 1996, 1998, 2000).

\section{Temperature optimum and growth at $4{ }^{\circ} \mathrm{C}$}

The optimum growth temperature for strain $\mathrm{T} 118^{\mathrm{T}}$ was $25^{\circ} \mathrm{C}$ (Fig. 3), but in long-term incubations, there was significant growth at temperatures as low as $4{ }^{\circ} \mathrm{C}$ (Fig. 4). $\mathrm{Fe}$ (III)-reducers capable of growth at such low temperatures have a competitive advantage in cold, Fe(III)-rich subsurface environments. Far northern aquifers and permafrost areas have sediment temperatures that remain at $0-8{ }^{\circ} \mathrm{C}$ (Zhang et al., 1999). Fe(III)-reducing enrichment cultures from marine sediment and Alaskan tundra permafrost reduced $\mathrm{Fe}$ (III) faster at $10^{\circ} \mathrm{C}$ than at $25^{\circ} \mathrm{C}$, indicating that some organisms may prefer cold temperatures for $\mathrm{Fe}$ (III) reduction (Zhang et al., 1999). However, strain $\mathrm{T}_{118^{\mathrm{T}}}$ is only psychrotolerant, not psychrophilic. 


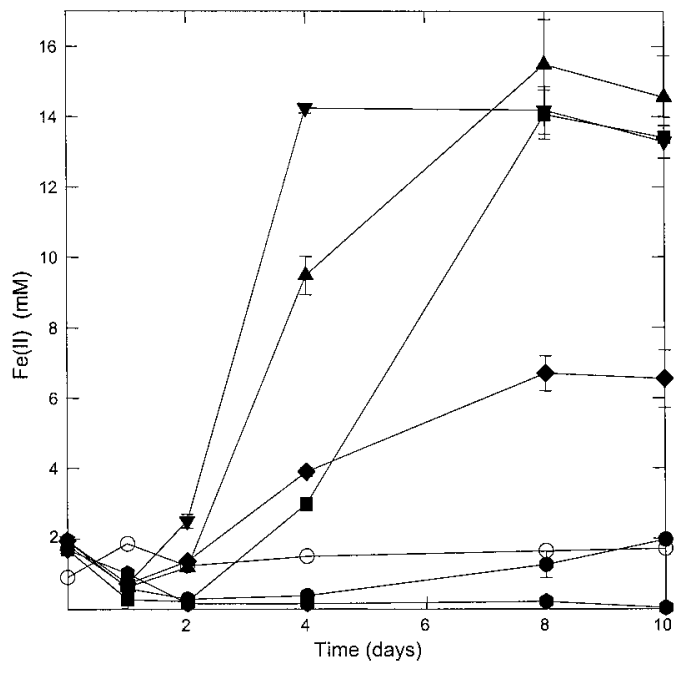

Fig. 3. Production of $\mathrm{Fe}(\mathrm{II})$ in cultures of $\mathrm{T} 118^{\top}$ with lactate $(20 \mathrm{mM})$ as the electron donor and Fe(III)-NTA $(10 \mathrm{mM})$ as the electron acceptor. $\bullet, 4^{\circ} \mathrm{C} ; \boldsymbol{\square}, 15^{\circ} \mathrm{C} ; \boldsymbol{\Delta}, 20^{\circ} \mathrm{C} ; \boldsymbol{\nabla}, 25^{\circ} \mathrm{C} ; \boldsymbol{\nabla}$, $30^{\circ} \mathrm{C} ; 37^{\circ} \mathrm{C} ; \bigcirc$, no cells. Results are the means of triplicate analyses. Error bars represent one standard deviation.

\section{Phylogeny}

Analysis of the $16 \mathrm{~S}$ rDNA sequence of strain $\mathrm{T}_{11} 8^{\mathrm{T}}$ indicated that its closest known relatives are Rhodoferax fermentans, Aquaspirillum delicatum and Rhodoferax antarcticus, with DNA similarity values of $97 \cdot 3,96 \cdot 5$ and $96 \cdot 4 \%$, respectively; 1420 bases were considered in all cases (Fig. 5). Neither the morphology nor the physiology of strain $\mathrm{T} 118^{\mathrm{T}}$ is consistent with the genus Aquaspirillum (Eden et al., 1991). Although strain $\mathrm{T}_{118^{\mathrm{T}}}$ is morphologically similar to previously described Rhodoferax species, these other species are not reported to grow via anaerobic respiration. Furthermore, strain $\mathrm{T} 118^{\mathrm{T}}$ did not grow phototrophically under conditions

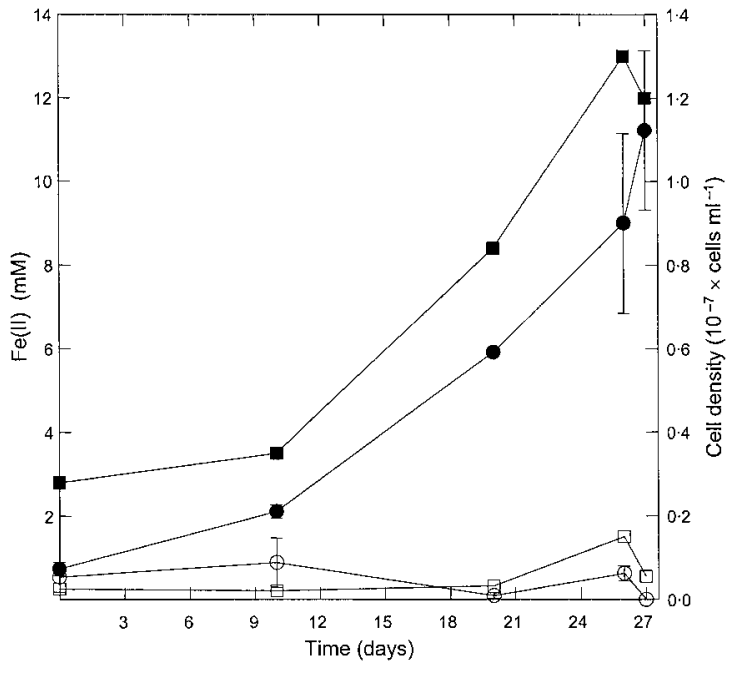

Fig. 4. Growth of $T 118^{\top}$ at $4^{\circ} \mathrm{C}$. $-\mathrm{Fe}(\mathrm{II})$ with lactate; $\bigcirc$, $\mathrm{Fe}$ (II) without lactate; $\mathbf{\square}$, cells with lactate; $\square$, cells without lactate. Results are the means of triplicate analyses. Error bars represent one standard deviation.

that support the growth of Rhodoferax species, nor could it ferment fructose, as has been reported in both Rhodoferax species that have been characterized to date (Hiraishi et al., 1991; Madigan et al., 2000). These physiological and phylogenetic differences are significant enough to warrant placing strain $\mathrm{T} 118^{\mathrm{T}}$ as a novel species within the genus Rhodoferax. The proposed name is Rhodoferax ferrireducens sp. nov.

\section{Description of Rhodoferax ferrireducens sp. nov.}

Rhodoferax ferrireducens (fer.ri.re.du'cens. L. n. ferrum iron; L. part. adj. reducens converting to a reduced oxidation state; N.L. part. adj. ferrireducens converting iron to a reduced oxidation state).

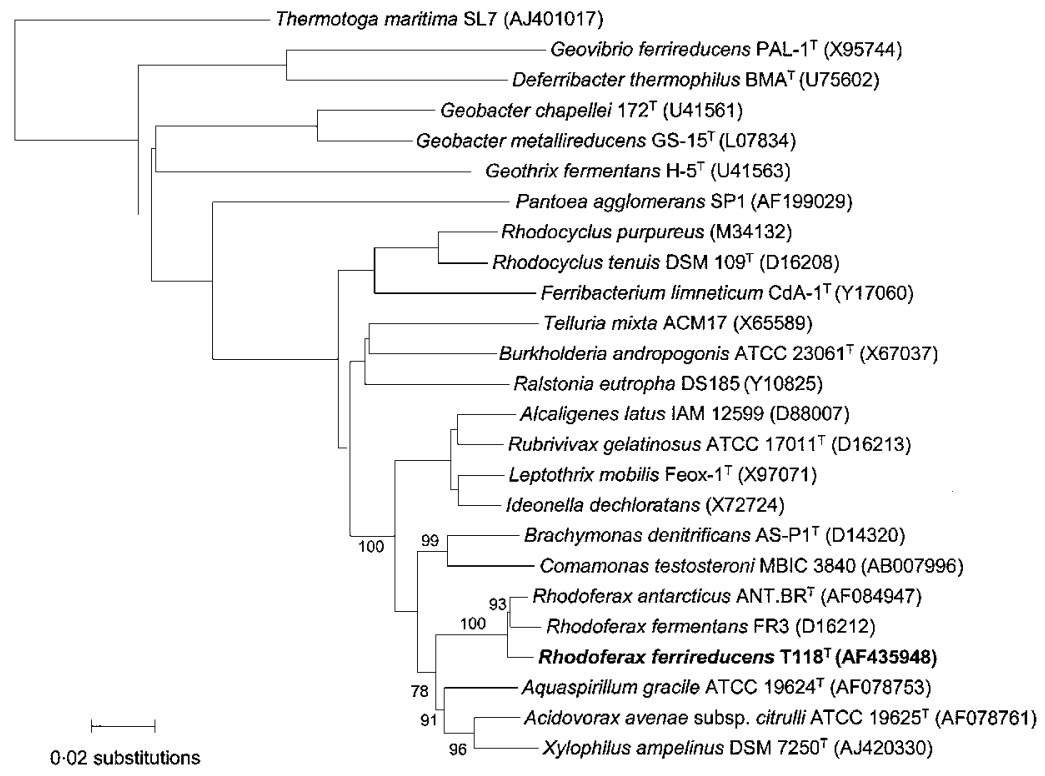

Fig. 5. Phylogenetic tree inferred from the neighbour-joining of distances calculated by the Kimura two-parameter model in TREECON for Windows with 1420 bases considered. Bootstrap values at nodes were calculated using 100 replicates. Bar, 0.02 nucleotide substitutions. 
Cells are Gram-negative, short rods, 3-5 $\mu \mathrm{m}$ long by $1 \mu \mathrm{m}$ wide, that are motile via a single polar flagellum. Colonies are glossy white, smooth, round and convex. Optimum temperature and $\mathrm{pH}$ are $25^{\circ} \mathrm{C}$ and $7 \cdot 0$, respectively. Grows at and reduces $\mathrm{Fe}(\mathrm{III})$ at temperatures as low as $4{ }^{\circ} \mathrm{C}$. There is no fermentative or phototrophic growth. Facultatively anaerobic: respires with $\mathrm{Fe}(\mathrm{III})-\mathrm{NTA}, \mathrm{Mn}(\mathrm{IV})$ oxide, fumarate, nitrate and atmospheric oxygen. AQDS, chromium(VI), cobalt-EDTA, elemental sulfur, poorly crystalline $\mathrm{Fe}(\mathrm{III})$ oxide, $\mathrm{Fe}(\mathrm{III})$ citrate, nitrite, $1 \%$ oxygen, selenate, selenite, sulfate, sulfite, thiosulfate and uranium(VI) are not reduced. Electron donors that are utilized include acetate, lactate, malate, propionate, pyruvate, benzoate and succinate. Does not utilize butanol, butyrate, caproate, ethanol, formate, glycerol, hydrogen, isobutyrate, methanol, propanol or valerate. PHA inclusion bodies fluoresce under UV light when stained with Nile blue A.

The type strain is $\mathrm{T} 118^{\mathrm{T}}\left(=\right.$ ATCC BAA- $621^{\mathrm{T}}=$ DSM $\left.15236^{\mathrm{T}}\right)$. Isolated from coastal aquifer sediment in Oyster Bay, VA, USA.

\section{ACKNOWLEDGEMENTS}

We would like to thank Elizabeth Blunt for her assistance with obtaining the Oyster Bay sediment and initiating the various enrichment cultures. We acknowledge Brian Pastens of Old Dominion University for samples from the Oyster Bay, VA, site. We also thank Lucy Yin of the University of Massachusetts microscopy facility for the electron microscopy, which is supported by NSF grant \# BBS 8714235. This research was funded by the Natural and Accelerated Bioremediation Research (NABIR) program, Biological and Environmental Research (BER), US Department of Energy (grant \# DE-FG02-00ER62985), and the Cooperative State Research Extension, Education Services, US Department of Agriculture, Massachusetts Agricultural Experiment Station, under project no. MASS00787.

\section{REFERENCES}

Brock, T. D., Madigan, M. T., Martinko, J. M. \& Parker, J. (1994). Biology of Microorganisms, 7th edn. Englewood Cliffs: Prentice Hall.

Caccavo, F., Jr, Coates, J. D., Rosselló-Mora, R. A., Ludwig, W., Schleifer, K. H., Lovley, D. R. \& Mclnerney, M. J. (1996). Geovibrio ferrireducens, a phylogenetically distinct dissimilatory $\mathrm{Fe}(\mathrm{III})$ reducing bacterium. Arch Microbiol 165, 370-376.

Coates, J. D., Councell, T. B., Ellis, D. J. \& Lovley, D. R. (1998). Carbohydrate oxidation coupled to Fe(III) reduction, a novel form of anaerobic metabolism. Anaerobe 4, 277-282.

Coates, J. D., Ellis, D. J., Gaw, C. V. \& Lovley, D. R. (1999). Geothrix fermentans gen. nov., sp. nov., a novel $\mathrm{Fe}(\mathrm{III})$-reducing bacterium from a hydrocarbon-contaminated aquifer. Int J Syst Bacteriol 49, 1615-1622.

Eden, P. E., Schmidt, T. M., Blakemore, R. P. \& Pace, N. R. (1991). Phylogenetic analysis of Aquaspirillum magnetotacticum using polymerase chain reaction-amplified $16 \mathrm{~S}$ rRNA-specific DNA. Int J Syst Bacteriol 41, 324-325.

Francis, C. A., Obraztsova, A. Y. \& Tebo, B. M. (2000). Dissimilatory metal reduction by the facultative anaerobe Pantoea agglomerans SP1. Appl Environ Microbiol 66, 543-548.

Greene, A. C., Patel, B. K. C. \& Sheehy, A. J. (1997). Deferribacter thermophilus gen. nov., sp. nov., a novel thermophilic manganeseand iron-reducing bacterium isolated from a petroleum reservoir. Int J Syst Bacteriol 47, 505-509.
Hiraishi, A., Hoshino, Y. \& Satoh, T. (1991). Rhodoferax fermentans gen. nov., sp. nov., a phototrophic purple nonsulfur bacterium previously referred to as the "Rhodocyclus gelatinosus-like" group. Arch Microbiol 155, 330-336.

Hobbie, J. E., Daley, R. J. \& Jasper, S. (1977). Use of nucleopore filters for counting bacteria by fluorescence microscopy. Appl Environ Microbiol 33, 1225-1228.

Kashefi, K. \& Lovley, D. R. (2000). Reduction of Fe(III), Mn(IV), and toxic metals at $100^{\circ} \mathrm{C}$ by Pyrobaculum islandicum. Appl Environ Microbiol 66, 1050-1056.

Kashefi, K., Tor, J. M., Holmes, D. E., Gaw Van Praagh, C. V., Reysenbach, A.-L. \& Lovley, D. R. (2002). Geoglobus ahangari gen. nov., sp. nov., a novel hyperthermophilic archaeon capable of oxidizing organic acids and growing autotrophically on hydrogen with $\mathrm{Fe}(\mathrm{III})$ serving as the sole electron acceptor. Int J Syst Evol Microbiol 52, 719-728.

Lovley, D. R. (2000a). Dissimilatory Fe(III)- and Mn(IV)-reducing prokaryotes. In The Prokaryotes. Edited by M. Dworkin, S. Falkow, E. Rosenberg \& E. Stackebrandt. New York: Springer.

Lovley, D. R. (2000b). Fe(III) and $\mathrm{Mn}(\mathrm{IV})$ reduction. In Environmental Microbe-Metal Interactions. Edited by D. R. Lovley. Washington, DC: American Society for Microbiology.

Lovley, D. R. \& Phillips, E. J. P. (1987). Rapid assay for microbially reducible ferric iron in aquatic sediments. Appl Environ Microbiol 53, $1536-1540$.

Lovley, D. R. \& Chapelle, F. H. (1995). Deep subsurface microbial processes. Rev Geophys 33, 365-381.

Lovley, D. R., Giovannoni, S. J., White, D. C., Champine, J. E., Philips, E. J. P., Gorby, Y. A. \& Goodwin, S. (1993). Geobacter metallireducens gen. nov. sp. nov., a microorganism capable of coupling the complete oxidation of organic compounds to the reduction of iron and other metals. Arch Microbiol 159, 336-344.

Lovley, D. R., Coates, J. D., Blunt-Harris, E. L., Phillips, E. J. P. \& Woodward, J. C. (1996). Humic substances as electron acceptors for microbial respiration. Nature 382, 445-448.

Lovley, D. R., Fraga, J. L., Blunt-Harris, E. L., Hayes, L. A., Phillips, E. J. P. \& Coates, J. D. (1998). Humic substances as a mediator for microbially catalyzed metal reduction. Acta Hydrochim Hydrobiol 26, 152-157.

Lovley, D. R., Kashefi, K., Vargas, M., Tor, J. M. \& Blunt-Harris., E. L. (2000). Reduction of humic substances and $\mathrm{Fe}(\mathrm{III})$ by hyperthermophilic microorganisms. Chem Geol 169, 289-298.

Madigan, M. T., Jung, D. O., Woese, C. R. \& Achenbach, L. A. (2000). Rhodoferax antarcticus sp. nov., a moderately psychrophilic purple nonsulfur bacterium isolated from an Antarctic microbial mat. Arch Microbiol 173, 269-277.

Rees, G. N., Vasiliadis, G., May, J. W. \& Bayly, R. C. (1992). Differentiation of polyphosphate and poly- $\beta$-hydroxybutyrate granules in an Acinetobacter sp. isolated from activated sludge. FEMS Microbiol Lett 94, 171-173.

Swofford, D. L. (1998). PAUP*: Phylogenetic Analysis Using Parsimony ( ${ }^{\star}$ and other methods) Sunderland, MA: Sinauer Associates.

Tor, J. M., Kashefi, K. \& Lovley, D. R. (2001). Acetate oxidation coupled to $\mathrm{Fe}(\mathrm{III})$ reduction in hyperthermophilic microorganisms. Appl Environ Microbiol 67, 1363-1365.

Vargas, M., Kashefi, K., Blunt-Harris, E. L. \& Lovley, D. R. (1998). Microbiological evidence for $\mathrm{Fe}(\mathrm{III})$ reduction on early earth. Nature 395, 65-67.

Zhang, C., Stapleton, R. D., Zhou, J., Palumbo, A. V. \& Phelps, T. J. (1999). Iron reduction by psychrotrophic enrichment cultures. FEMS Microbiol Ecol 30, 367-371. 